\title{
PELATIHAN SELF HYPNOSIS UNTUK MENCEGAH WORK BURNOUT DAN MENINGKATKAN KINERJA DOSEN DENGAN METODE BLENDED LEARNING DI UNIVERSITAS WIRARAJA
}

\author{
${ }^{1)}$ Dr.Eko Mulyadi.S.Kep.,Ns.M.Kep, ${ }^{2)}$ Iva Gamar Pratiwi.S.ST.,M.Kes, \\ ${ }^{3}$ Syaifurrahman Hidayat .S.Kep.,Ns.M.Kep \\ ${ }^{1,2,3)}$ Fakultas Ilmu Kesehatan Universitas Wiraraja \\ Email : ${ }^{1)}$ eko.wiraraja@gmail.com, ${ }^{2)}$ ivagamar@wiraraja.ac.id. ${ }^{3)}$ dayat.fik@wiraraja.ac.id.
}

\section{ABSTRAK}

Hasil survey awal dari 10 dosen di Universtitas Wiraraja didapatkan 60\% mengatakan pernah stress, terutama saat deadline seperti persiapan untuk akreditasi. berdasar data dari klinik Wiraraja Medika, terdapat 20 kasus psikosomatik pada tahun 2018 di Universitas Wiraraja, hal ini menggambarkan bahwa kejadian distress cukup tinggi di Universitas Wiraraja, sedangkan di Klinik Wiraraja Medika belum ada pelayan spesifik untuk mengatasi masalah psikosomatik. Kondisi distress yang tidak tertangani dapat menyebabkan burn out sehingga dapat menggangu kinerja pada dosen dan civitas akademika, resiko burn out bertambah terutama pada dosen yang mempunyai peran ganda, misalnya pada dosen yang masih kuliah dan bekerja serta masih mengurus keluarga. Tujuan dari kegiatan ini untuk memberikan keterapilan melakukan self hypnosis (hypnosis untuk diri sendiri) sehingga dapat mengatasi stress kemudian dapat mencegah terjadinya work burn out sehingga dapat meningkatkan kinerja. Metode yang dipakai adalah dengan pelatihan dengan pendekatan blended learning menggabungkan metode pelatihan tatap muka langsung dan pelatihan daring menggunakan conference call. pelatihan ini bekerja sama dengan klinik wiraraja medika di Universitas Wiraraja

Keyword : self hypnosis, stress, burnout, kinerja

\section{PENDAHULUAN}

Universitas wiraraja merupakan perguruan tinggi swasta dengan urutan ke 371 dari seluruh perguruan tinggi di Indonesia, saat ini jumlah perguruan tinggi seluruh Indonesia sebanyak 2010 termasuk perguruan tinggi negeri dan swasta(DIKTI, 2019). Semakin meningkatnya persaingan antar perguruan tinggi memaksa dosen dan civitas akademika bekerja keras untuk tetap bertahan. Dosen dituntut untuk melakukan kewajiban tridarma perguruan tinggi, berdasar hasil wawancara dengan dosen wiraraja, mereka mengeluhkan bahwa publikasi internasional bereputasi merupakan tantangan terberat saat ini. Selain membutuhkan keahlian dan pengalaman, juga membutuhkan biaya yang cukup besar untuk mempublikasikan karya ilmiahnya di jurnal inernasional bereputasi. Hal ini menyumbang tingkat stress pada dosen. Jika stess yang jika tidak ditangani dengan baik dapat menyebabkan banyak masalah salah satunya adalah burn out. Kondisi burn out berpotensi menurunkan kinerja (Marriane, 2006). Sehingga berpotensi merugikan bagi universitas wiraraja

Berdasar hasil survey awal dari 10 dosen dan karyawan didapatkan $60 \%$ mengatakan pernah stress, terutama saat dikejar deadline seperti persiapan untuk akreditasi. Kondisi distress yang tidak tertangani dapat menyebabkan burn out sehingga dapat menggangu kinerja pada dosen dan karyawan, resiko burn out bertambah terutama pada dosen yang mempunyai peran ganda, misalnya pada dosen yang masih kuliah dan bekerja serta masih mengurus keluarga 
Metode yang digunakan untuk penyelesaian masalah ini dengan memberikan pelatihan self hypnosis, pelatihan ini dilakukan dengan pendekatan blended learning, menggabungkan tatap muka langsung dan pelatihan daring menggunakan conference call. Metode ini digunakan karena lebih fleksibel sehingga peserta tidak perlu selalu berkumpul untuk mengikuti pelatihan,

Burnout menggambarkan perasaan kegagalan dan kelesuan karena tuntutan yang terlalu membebankan tenaga dan kemampuan seseorang. pertama kali dikenalkan oleh Freudenberger pada tahun 1974. Penelitian selama subjek tersebut disugesti untuk mengalami suatu pengalaman imajinatif.(Elkins, Barabasz, Council, \& Spiegel, 2015) sedangkan self hypnosis adalah penggunaan hypnosis untuk diri sendiri, pada dasarnya semua hypnosis adalah self hypnosis, karena pada dasarnya hypnoterapi hanya memandu untuk memasuki kondisi hypnosis, namun orang tergantung pada orang yang dihipnosis mau atau tidak memasuki kondisi tesebut.

Adapun target dan luaran dari pengabdian kepada masyarakat ini agar mitra memahami self hypnosis dan mampu mempraktikkan self hypnosis serta memahami proses terjadinya stress sehingga tingkat stress dapat berkurang sehingga outcome yang didapat kinerja dapat meningkat

\section{METODE PELAKSANAAN}

Untuk mengurangi burn out dan meningkatkan kinerja dosen, maka dilakukan pelatihan self hypnosis, menggunakan tiga tahapan untuk membuat peserta dapat melakukan self hypnosis dengan baik,

\section{Tahap 1}

mengenai topik ini pertamakali dilakukan dibidang pendidikan, yaitu pada guru yang mengalami penurunan kinerja yang disebabkan oleh burnout. Burn out pertama kali dikenal sebagai masalah social dan tidak termasuk dalam konsep akademik, namun berjalannya waktu banyak penelitian mengenai burnout sehingga fenomena ini semakin banyak dikenal dalam dunia akademik. (Maslach, Schaufeli, \& Schaufeli, 2017)

Menurut American psychology association Hipnosis pada umumnya terkait dengan pengenalan sebuah prosedur

Pada tahap awal dilakukan screening tingkat depresi, burn out dan kinerja, kemudian mengidentifikasi mekanisme koping dan kepribadian peserta, dalam tahap ini diharapkan peserta memahami kepribadiannya sendiri, sehingga mengetahui kelebihan, kekurangannya, pada tahap ini sebagai modal untuk memperbaiki diri menggunakan pendekatan self hypnosis, menggunakan pendekatan pelatihan dengan teori $30 \%$ dan praktik $70 \%$ sehingga peserta langsung dapat mempraktikkan self hypnosis. Peserta dilakukan pemeriksaan kesehatan dasar di klinik wiraraja medika, sedangkan tempat pelaksanaan dilakukan di laboratorium keperawatan di fakultas ilmu kesehatan.

\section{Tahap 2}

Pada tahap kedua peserta melakukan praktik hipnosis dengan bimbingan trainer, target pada tahap kedua adalah mengetahui permasalahan yang dihadapi peserta baik yang disadari dan yang tidak disadari melalui hipnosis, kemudian peserta memperbaiki mekanisme koping, response, dan persepsi peserta tentang stress, peserta kemudian melaksanakan secara mandiri di rumah, follow up dan bimbingan dilakukan dengan video conference call. dan group whatsapp. Untuk memastikan peserta 
melaksanakan dan mengatasi kendala saat self hypnosis.

\section{Tahap 3}

Target dari tahap ketiga tingkat depresi,burn out berkurang dan kinerja meningkat, peserta juga mampu melaksanakan secara mandiri self hypnosis. Dalam tahapan ini diaharapkan peserta telah memperbaiki mekanisme koping, response serta persepsi tentang stress, dihasapkan juga peserta mampu mensintesis dan memodifikasi praktik self hypnosis sesuai kebutuhan peserta. Adapun tahapan pelatihan self hypnosis tergambar dalam gambar sebagai berikut.

Gambar 1. Kerangka penyelesaian masalah burn out dan kinerja dengan pendekatan Self Hypnosis

keterangan :

pelaksanaan dibagi menjadi 3 tahapan, pada tahap pertama tatap muka langsung, tahap kedua follow up, tahap ketiga evaluasi
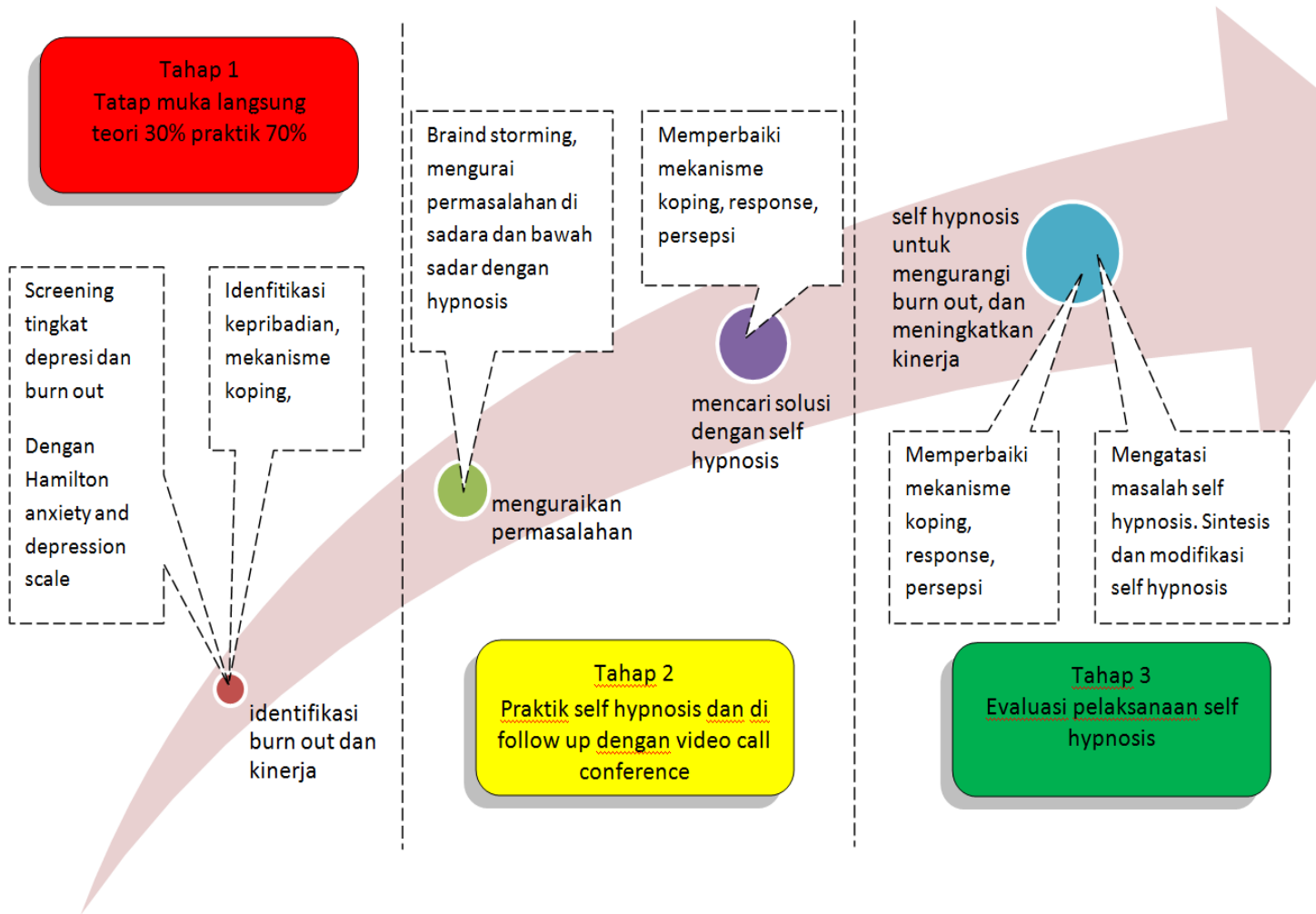

\section{PELAKSANAAN KEGIATAN}

Adapun tahapan pelaksanaan kegiatan tergambar dalam diagam sebagai berikut Tahapan pelaksanaan pelatihan self hypnosis

Minggu 1 (tahap 1)

- Memahami tingkat depresi dan sugestibilitas

- Memahami konsep dasar self hypnosis

- Mampu mempraktikkan self hypnosis

Minggu 2 (tahap 2)

\section{Pendaftaran peserta}

Pelatihan1 (tatap muka langsung)

a. pembukaan pelatihan dan

penjelasan rencana pelaksanaan

30

- Mahir melaksanakan self hypnosis

- Mampu mengatasi kendala pelatihan

b. screening tingkat depresi dan

tingkat sugestibilitas

c. konsep dasar self hypnosis

e. praktik self hypnosis self hypnosis 
Pelatihan2 (daring)

a. follow up pelaksanaan self

hypnosis

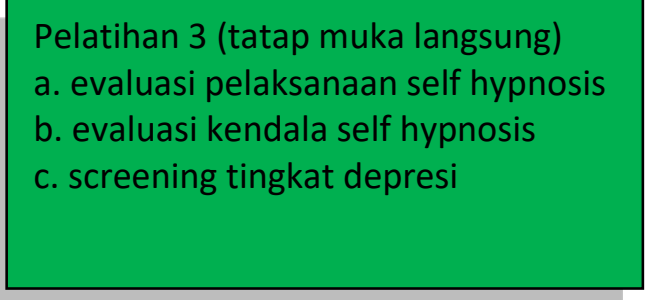

Diagram 2. Pelaksanaan pelatihan self hypnosis

Keterangan : pelaksanaan dilakukan selama 3 minggu dengan target berbeda setiap minggu. Pada minggu terakhir peserta mampu melakukan self hypnosis dan berimprofisasi.

\section{HASIL DAN PEMBAHASAN}

Pelaksanaan kegiatan dilakukan dengan 3 tahapan selama 3 minggu, setiap tahapan mempunyai target sendiri, dan setiap tahapan menggunakan metode berbeda, pelaksanaan kegiatan menggunakan metode blended learning, dengan menggabungkan pembelajaran tatap muka langsung dengan metode ceramah $30 \%$ dan praktik $70 \%$, pembelajaran daring dilakukan untuk follow up pelaksanaan self hypnosis dirumah menggunakan video conference call. Adapun penjelasannya sebagai berikut:

\section{Tahap 1}

Pelaksanaan tahap 1 dilakukan pada minggu pertama, dimulai dengan pendaftaran peserta, screening tingkat depresi dan tingkat sugestibilitas peserta, kemudian dilakukan pelatihan dasar dasar hipnosis dan praktik self hypnosis, adapun target dalam tahapan ini peserta memahami tingkat depresi dan sugestibilitas, konsep dasar hypnosis dan mampu mempraktikan self hypnosis, metode pelatihan dengan pendampingan langsung dengan $30 \%$ teori dan $70 \%$ praktik

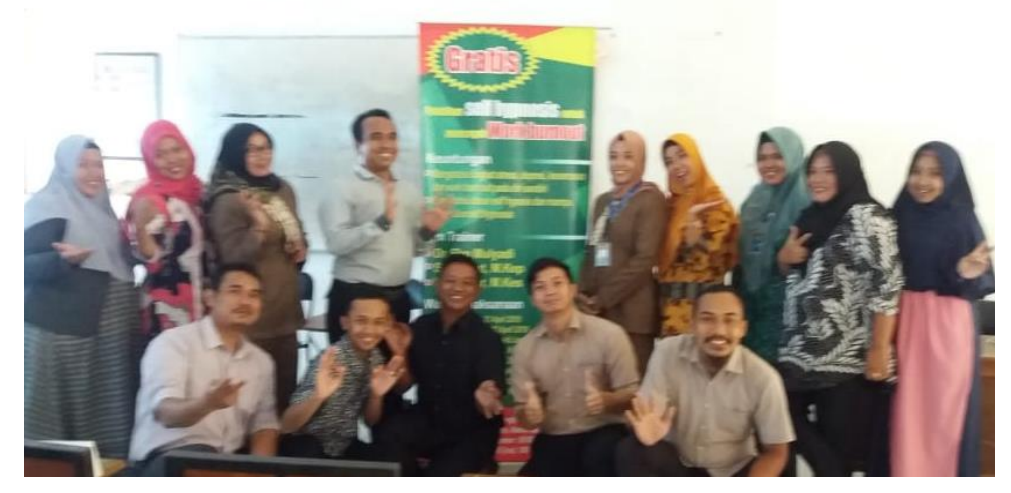




\section{Gambar 1 pelaksanaan pelatihan self hypnosis}

Keterangan : pelatihan diikuti oleh dosen dan karyawan di universitas wiraraja, dengan praktik langsung self hypnosis

Pelaksanaan self hypnosis dihadiri 14 peserta dari peserta terdaftar sebanyak 20 peserta, pelaksanaan belangsung selama 1.5 jam dengan teori dan praktek,

\section{Tahap 2}

Pelaksanaan tahapan 2 dilakukan pada minggu kedua, peserta sudah dapat melaksanakan self hypnosis dengan mandiri, peserta tetap di lakukan follow up secara daring, menggunakan video call conference dan group whatsapp, pada tahapan ini peserta diharapakan mampu mengatasi kendala dalam pelaksanaan self hypnosis

sebelum melakukan self hypnosis peserta diberikan kuisioner untuk mengetahui tingkat depresi, kecemasan dan stress. Berikut ini adalah diagram tingkat depresi, kecemasan, dan stress,

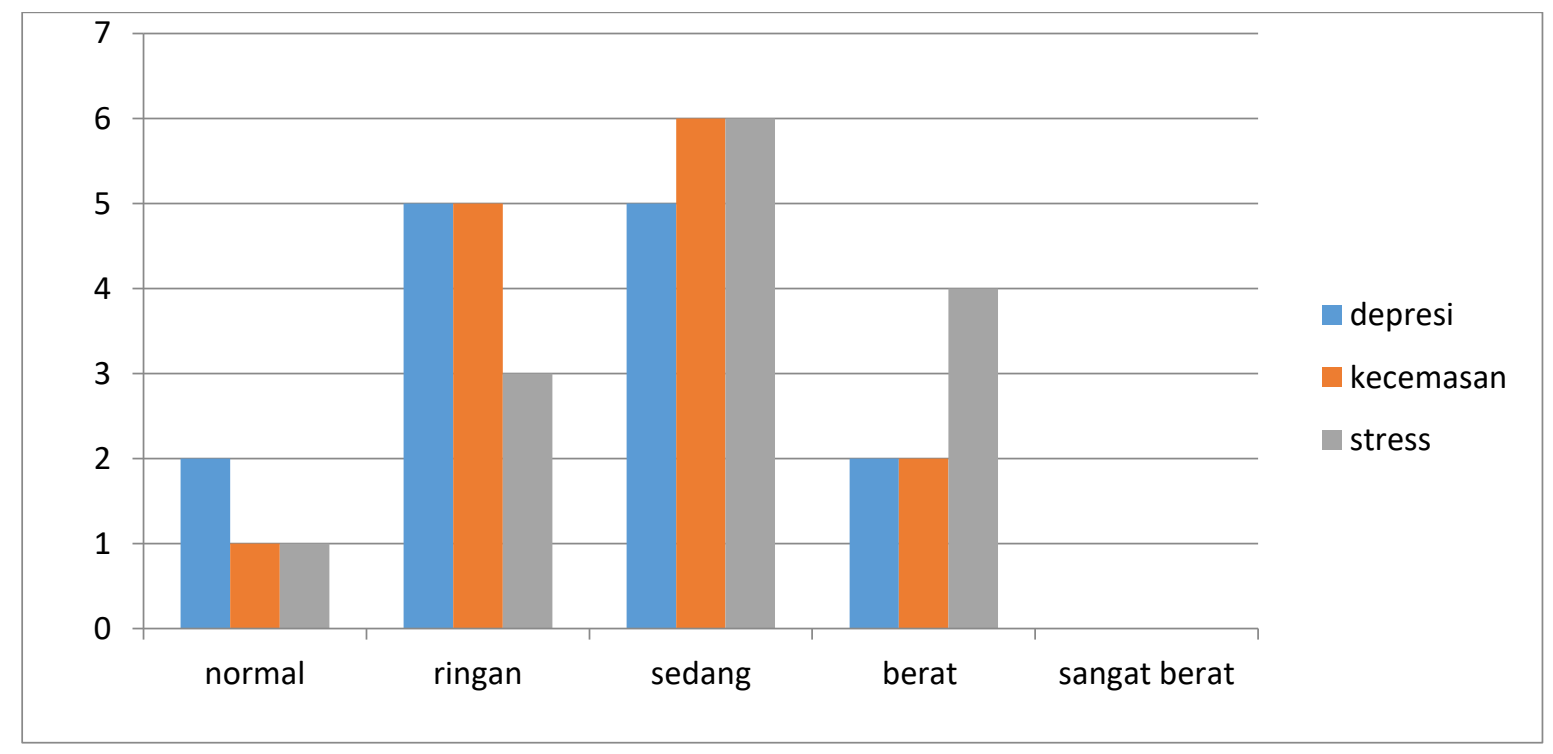

Grafik 1. Tingkat depresi, kecemasan dan stress sebelum pemberian self hypnosis

Keterangan: sebagian besar tingkat kecemasan,depresi dan stress berada pada level sedang. Dan tidak ada yg sangat berat

\section{Tahap 3}

Pada tahapan ini dilakukan evaluasi pelaksanaan self hypnosis, dan kendala yang dihadapi, peserta juga dilakukan penilaian tingkat depresi dan burn out kembali, termasuk kinerja. Peserta dapat mensinesis self hypnosis 
dan berimprofisasi untuk menyesuaikan dengan kebutuhan dirinya.

Berikut ini adalah grafik tingkat depresi, kecemasan dan stress setelah diberikan self hypnosis, tampak penurunan tingkat depresi, kecemasan dan stress dibandingkan sebelum diberikan self hypnosiss

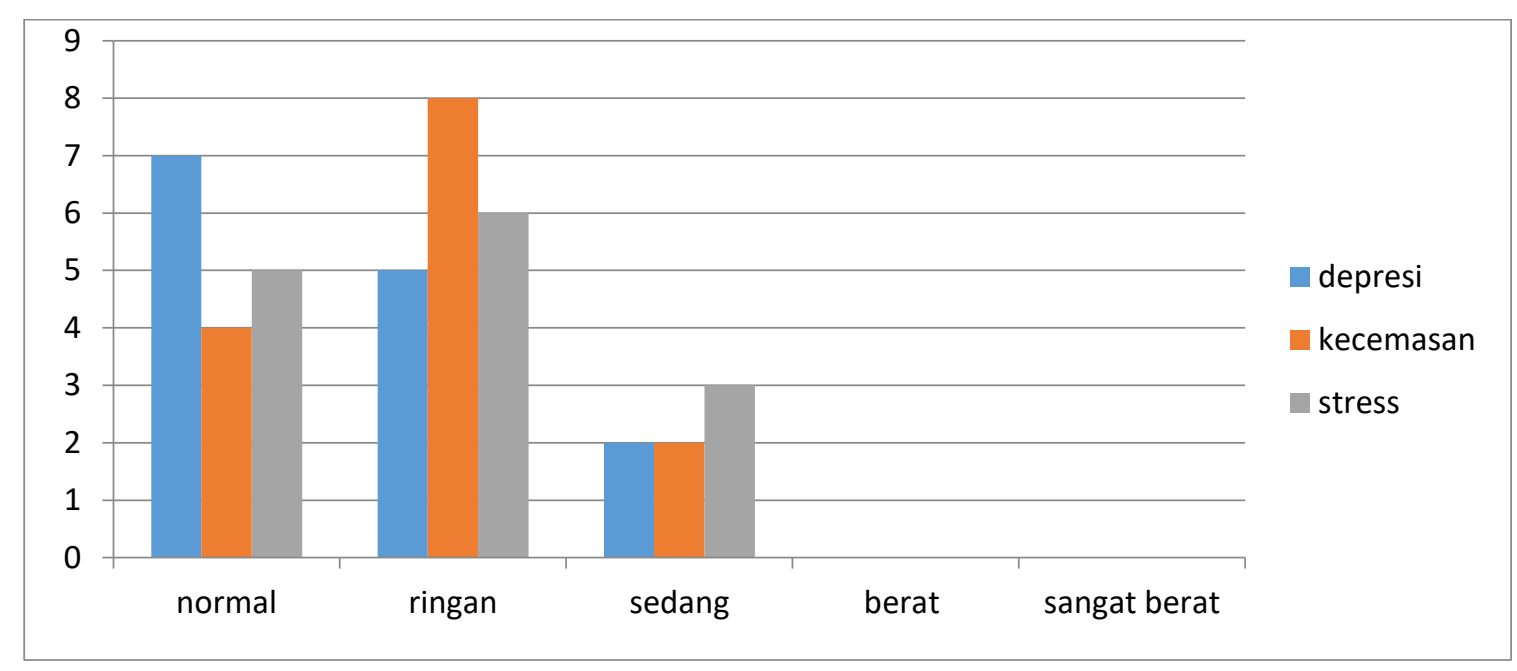

Grafik 2.tingkat depresi, kecemasan dan stress setelah diberikan self hypnosis

Keterangan: sebagian besar tingkat kecemasan,depresi dan stress berada pada level ringan. Dan tidak ada yg berat atau sangat berat, yang menunjukkan pelatihan ini dapat mengurangi tingkat depresi,stress dan kecemasan

\section{KESIMPULAN DAN SARAN}

Kesimpulan dari kegiatan ini didapatkan sebagai berikut

1. Sebagian besar peserta mengalami depresi, stress dan kecemasan pada tingkat sedang

2. Setelah diberikan self hypnosis terdapat penurunan tingkat depresi,stress dan kecemasan, menjadi normal dan ringan

3. Melakukan pelatihan self hypnosis untuk seluruh karyawan dan dosen untuk mengurangi tingkat depresi, stress dan kecemasan.
3. Peserta dapat melakukan self hypnosis, Saran berdasar kegiatan ini untuk perbaikan di masa depan adalah

1. Melakukan screening tingkat depresi, stress dan kecemasan secara berkala

2. Melakukan kegiatan yang dapat mengurangi stress depresi dan kecemasan, seperti outbond dan gathering

\section{DAFTAR PUSTAKA}

DIKTI. (2019). DIKTI. Diambil 22 Februari 2019, dari http://pemeringkatan.ristekdikti.go.id/i ndex.php/pemeringkatan

Elkins, G. R., Barabasz, A. F., Council, J. R., \& Spiegel, D. (2015). Advancing 
Research and Practice: The Revised APA Division 30 Definition of Hypnosis. International Journal of Clinical and Experimental Hypnosis, 63(1), $1-9$. https://doi.org/10.1080/00207144.201 4.961870

Marriane, B. (2006). Burnout among employees in human service work: design and baseline findings of the PUMA study - Marianne Borritz, Reiner Rugulies, Jakob B. Bjorner, Ebbe Villadsen, Ole A. Mikkelsen, Tage S. Kristensen, 2006. Diambil 22 Februari 2019, dari https://journals.sagepub.com/doi/abs/1 0.1080/14034940510032275

Maslach, C., Schaufeli, W. B., \& Schaufeli, W. B. (2017). Historical and Conceptual Development of Burnout. https://doi.org/10.4324/978131522797 9-1 